\title{
OPTIMAL MANUFACTURING/REMANUFACTURING POLICIES WITH FIXED INVESTMENT FOR THE UNDERDEVELOPED REMANUFACTURING SYSTEM
}

\author{
Xiang Lv, Jian-Hua Huang, Hai-Bo Liu
}

Original scientific paper

In an underdeveloped remanufacturing system, poor infrastructure and low technical level impede further development of remanufacturing. To overcome this obstacle, a huge amount of fixed investment is required to improve the remanufacturing system. However, this investment inevitably influences the manufacturer's manufacturing/remanufacturing decision-making economically. The relationship between fixed investment and recycling ratio was investigated, and the two- and multi-period manufacturing/remanufacturing mixed optimization models were developed. Based on the Karush-KuhnTucker (KKT) conditions, the optimal manufacturing/remanufacturing and fixed investment policies were obtained in closed-form expressions. Moreover, the influences of the fixed investment were analysed. Results show that the optimal policies are significantly influenced by the degree of underdevelopment of the remanufacturing system. When the remanufacturing system is underdeveloped, the manufacturer shows a lack of enthusiasm in remanufacturing, thereby resulting in the decrease of the investment and the recycling ratio. The manufacturer raises the sale price to alleviate the loss caused by fixed investment, but the total manufacturing quantity and profit decrease. In the multi-period case, the manufacturer gradually increases the investment for continuously improving the remanufacturing system to increase the recycling ratio and obtain additional profits from remanufacturing. The proposed models can effectively provide the reference for determining the reasonable manufacturing/remanufacturing and fixed investment policies in the underdeveloped remanufacturing system.

Keywords: fixed investment; heterogeneous demands; KKT conditions; remanufacturing

Smjernice za optimalnu proizvodnju/preradbu s fiksnim ulaganjem u nedovoljno razvijeni sustav preradbe

Izvorni znanstveni članak U nedovoljno razvijenom sustavu preradbe, slaba infrastruktura i nizak tehnički nivo onemogućavaju daljnji razvoj preradbe. Za otklanjanje ove prepreke i unapređenje sustava preradbe potrebna su velika fiksna ulaganja. Ta ulaganja nedvojbeno utječu na proizvođača i ekonomičnost u donošenju odluke o proizvodnji /preradbi. Analizirao se odnos između omjera fiksnog ulaganja i preradbe te su razvijeni modeli optimizacije s dva i više perioda proizvodnje/preradbe. Na temelju Karush-Kuhn-Tucker (KKT) uvjeta, dobivene su smjernice za optimalnu proizvodnju/preradbu i fiksno ulaganje. Uz to, analizirani su učinci fiksnog ulaganja. Rezultati pokazuju da na optimalne odluke značajno utječe stupanj nerazvijenosti sustava preradbe. Kad je sustav preradbe nedovoljno razvijen, proizvođač pokazuje manjak entuzijazma za prerađivanje, a to dovodi do smanjenja ulaganja i omjera preradbe. Proizvođač podiže prodajnu cijenu kako bi ublažio gubitak izazvan fiksnim ulaganjem, ali ukupna proizvodnja i profit opadaju. U slučaju multi-perioda, proizvođač postepeno povećava ulaganje u trajno poboljšanje sustava preradbe kako bi se povećao omjer recikliranja i dobila dodatna zarada od preradbe. Predloženi modeli mogu dati učinkovite reference za određivanje odgovarajućih smjernica o proizvodnji/preradbi i fiksnom ulaganju u nedovoljno razvijenom sustavu preradbe.

Ključne riječi: fiksno ulaganje; heterogena potražnja; KKT uvjeti; preradba

\section{Introduction}

Resource conservation and environmental protection gain increasing attention with the development of human society [1]. Remanufacturing, a critical link for sustainable development, focuses on increasingly important issues. In particular, "it can extend the product life cycle, and reduce resource consumption and waste generation over entire life cycle" [2]. For example, energy consumption is cut by 68 to $83 \%$, and carbon emissions are reduced by 73 to $87 \%$ during the production process of remanufacturing auto engines in the United States, leading to the sale price reduction by approximately 30 to $50 \%$ of the new product price [3]. Remanufacturing is also favourable for increasing number of manufacturing clients. For example, International Business Machines Corporation (IBM) set up the first server remanufacturing centre in China. More than 100,000 sets of PC, mediumand low-end IBM, and non-IBM servers are remanufactured annually. This remanufacturing system contributes to the expansion of the remanufacturing business of IBM on a global scale (including Australia, Singapore, Japan, and Brazil) [2].

However, the operational process of remanufacturing is complex. Manufacturers handle many waste products of different types and quality standards. A survey suggests that American manufacturers must recycle more than
1,400 and 50,000 kinds of waste products and parts each year, respectively, on average [4]. Remanufacturing typically relies on complete recycling network, advanced remanufacturing techniques, and high environmental protection and recycling awareness for its successful implementation. In developing countries (especially, China, India, and Brazil), remanufacturing remains in its preliminary development stage, which is characterized by weak recycling awareness among consumers, incomplete recycling networks of waste products, and low level of remanufacturing techniques. Manufacturers frequently invest substantially in improving the remanufacturing system. However, significant amount of fixed investment reduces the enthusiasm of manufacturers and influences their remanufacturing decision-making. Therefore, this study aims to explore the influence of fixed investment on manufacturer's decision-making in the underdeveloped remanufacturing system, which can effectively relieve the manufacturers' problems.

Currently, research on manufacturing/ remanufacturing system is limited to developed countries and regions. These countries and regions provide complete recycling networks and remanufacturing system and formulate strict environmental protection regulations, requiring manufacturers to implement remanufacturing accordingly $[5,6]$. Moreover, manufacturers and consumers have robust environmental awareness in 
developed countries and regions [7]. These factors aid in decreasing the fixed investment of manufacturers to a level in which its influences are nearly ignored [8]. Existing research findings are not completely applicable to manufacturing/remanufacturing decision-making in the underdeveloped remanufacturing system. Hence, we consider additional practical situations of the countries with the underdeveloped remanufacturing system, and expand the research to discuss the influences of the fixed investment on the manufacturing/remanufacturing policies.

In this study, we first analyse the relationship between fixed investment and recycling ratio in the underdeveloped remanufacturing system, and the corresponding function is formulated. In addition, the consumer perceived values of new and remanufactured products are differentiated. The two- and multi-period manufacturing/remanufacturing mixed optimization models are formulated under the heterogeneous demands. Reasonable manufacturing/remanufacturing and fixed investment policies are proposed to alleviate the negative influences caused by huge fixed investment in the underdeveloped manufacturing system.

The rest of this study is organized as follows. In Section 2, related literature is discussed, and the differences between the present study and the literature are analysed. In Section 3, the two-stage manufacturing/remanufacturing mixed optimization model is developed under the heterogeneous demand. Moreover, the optimal closed-form solution is derived, and the influences of fixed investment on the optimal decisions are analysed. In addition, the multi-stage model is extended. In Section 4, numerical simulations are conducted to obtain managerial insights. Section 5 concludes the study with future research directions.

\section{State of the art}

Remanufacturing has been increasingly recognized as a business model that is not only profitable, but also competitive. It has attracted considerable attention from researchers due to its benefits. Previous studies have covered remanufacturing logistics network, closed-loop supply chain coordination based on remanufacturing, joint manufacturing/remanufacturing decision-making, pricing of remanufactured products, and acquisition of waste products [9]. Among these issues, manufacturing/ remanufacturing is a critical factor influencing manufacturers' decision-making.

At present, the joint manufacturing/remanufacturing decision-making is investigated intensively. Kleber et al. obtained the optimal manufacturing/remanufacturing and recovery policies under the condition of the linear costs to select multiple remanufacturing modes [10]. Ferrer and Swaminathan discussed the joint manufacturing/ remanufacturing decision-making problem under the heterogeneous demands given recycling ratio [11]. Guide $\& \mathrm{Li}$ analysed how the cannibalization of remanufactured products influences the optimal manufacturing/ remanufacturing policies [12]. Wang et al. studied the manufacturing/remanufacturing decision-making problem for products with brief life cycle under the random demands and quantities of recyclable products and extensively discussed the influences of the percentage of remanufactured products on the total cost of the mixed production system [13]. Shi et al. developed a singleperiod mixed production model to maximize expected profits under the uncertainties of the demands and quantities of recyclable products [14]. Li et al. assumed that the quantity of recyclable products is random and dependent on the recycling price and obtained the optimal manufacturing/remanufacturing and recycling price policies [15]. Cai et al. examined the issue of production and recycling price in the manufacturing/remanufacturing system when the recyclable products have different quality standards and concluded that the quantity of recyclable products is linearly correlated with the recycling price [16]. Bulmus et al. studied a mixed manufacturing/remanufacturing problem when the original equipment manufacturer competes with the independent remanufacturer under heterogeneous demands [17]. In the literature, it is assumed that manufacturers can obtain adequate waste products and reach the statutory recycling ratio, which is based on the developed recycling channels and networks. That is, the capital input for improving the remanufacturing system is ignored. However, this conclusion is contrary to practical situations, especially for underdeveloped remanufacturing systems in developing countries and regions.

The remanufacturing business in developing countries and regions is hindered by recycling network, recycling awareness of customers, and quantity of recyclable products. Given these hurdles, a remanufacturing market presenting perfect competition cannot be established in these countries and regions. For example, the waste part recycling network in the auto industry of China is incomplete. Moreover, the existence of large-scale grey recyclers increases the recycling cost of legitimate manufacturers, thereby impeding the latter from expanding their remanufacturing business. Manufacturers must invest huge funds to improve the remanufacturing system so that the adequate recyclable products can be acquired [18].

The above analysis implies that the remanufacturing system in developing countries is regressive, resulting in huge investments for improving of the recycling ratio. The recycling ratio is an endogenous variable and directly depends on fixed investments. Furthermore, the recycling ratio increases with fixed investment, linearly or quadratically, which negatively influences the manufacturer's decision-making. Yang et al. discussed these negative influences in the underdeveloped remanufacturing system [8]. However, the literature assumes that the demands for new products and remanufactured products are homogeneous. That is, no difference is observed between consumer perceived values of new and remanufactured products. In practice, manufacturers are usually required to clearly label new and remanufactured products to protect the legitimate rights and interests of consumers. Therefore, the consumer perceived values of the two kinds of products should be differentiated [19]. The demands for new and remanufactured products are heterogeneous, and influence the decision-making of manufacturers.

Compared with the aforementioned literature, we represent the underdevelopment of the remanufacturing 
system by the recycling ratio and formulate the function between recycling ratio and fixed investment. A twoperiod manufacturing/remanufacturing model is developed under heterogeneous demands to maximize the expected profit of manufacturers. The optimal manufacturing/remanufacturing and fixed investment policies are obtained in the closed-form expressions. In addition, an analytical approach is adopted to discuss the influences of fixed investment on the optimal policies. Furthermore, the two-period model is extended to the multi-period case to better support manufacturer's decision-making.

\section{Methodology}

\subsection{Problem description and hypotheses}

In this study, a two-period manufacturing/ remanufacturing model is proposed in an underdeveloped remanufacturing system. This study considers a single manufacturer condition, in which the manufacturer produces new and remanufactured products simultaneously for profits or compliance with relevant environmental policies and regulations. In the first period, the manufacturer produces new products as the oligopoly. In the second period, the manufacturer produces new products and acquires the products sold in the first period for remanufacturing. Both product types are sold in the same market. The manufacturer determines the investment amount for improving the remanufacturing system and the quantities of the new and remanufactured products.

The following hypotheses are formulated prior to modeling:

(1) The new or remanufactured products are sold out in each period.

(2) The remanufactured products are labeled to distinguish them from new products. Moreover, the consumer perceived values of the new and remanufactured products vary. The consumer perceived value of new products is $\mathrm{v}$ and follows the uniform distribution in $[0,1]$. The consumer perceived value of remanufactured products is $\alpha v$, where $\alpha$ is the coefficient of public awareness of environmental protection, and $0<\alpha<1$.

(3) The acquisition and remanufacturing of manufacturers are under government monitoring. The manufacturer must invest their funds, $I$, to improve the recycling ratio $\rho$ in the underdeveloped remanufacturing system. The funds are used to construct the recycling channels and networks, and the advertisement and publicity of the recycling activities. According to [20], $I=(K / 2) \rho^{2}$, where $K$ is an investment coefficient. Moreover, the remanufacturing system is underdeveloped when $K$ is large. That is, the manufacturer should invest more funds if the recycling ratio is given.

The notation of the models is listed as follows.

Subscripts:

$i$ : Production period, $i \in\{1,2, \cdots, M\}$

$j$ : Product category, $j \in\{n, r, a\}$, where $j=n$ denotes new products, $j=r$ denotes remanufactured products, and $j=a$ denotes all products, including new and remanufactured products
Superscripts:

*: The optimal policies of manufacturers

Variables:

$c_{n}$ : Unit production cost of new products

$c_{r}$ : Unit production cost of remanufactured products

$\alpha$ : Coefficient of public awareness on environmental protection

$v$ : Consumer perceived value of new products

$p_{i, j}$ and $q_{i, j}$ : Price and demand of product $j$ in period $i$, respectively. Only new products are considered in the first period, thus the subscript $j$ is omitted.

$\Delta:$ Scale of the market

$\rho_{i}$ : Recycling ratio of period $i$, and $0<\rho_{i}<1, i=2,3, \ldots$, $M$

$\theta$ : Risk-free return rate, and $0<\theta<1$. When the time value of the funds is considered, the discount coefficient of the expected profit is $\beta=1 /(1+\theta)$

$K_{i}$ : Investment coefficient of period $i$, and $i=2,3, \ldots, M$.

\subsection{Two-period model \\ 3.2.1 Model formulation}

In the first period, only new products are considered in the market. If consumer utility, $v-p_{1}$, is no less than zero, then new products will be purchased. Accordingly, the demand for new products can be formulated as follows:

$$
q_{1}=\Delta \int_{p_{1}}^{1} \mathrm{~d} F(v)=\Delta\left(1-p_{1}\right)
$$

In the second period, new and remanufactured products are in the market. When $v-p_{2 n} \geq 0$ and $v-p_{2 n} \geq$ $\alpha v-p_{2 r}$, consumers purchase the new products. When $\alpha v$ $-p_{2 r} \geq 0$ and $\alpha v-p_{2 r} \geq v-p_{2 n}$, consumers purchase the remanufactured products. In this study, the demands for new and remanufactured products are expressed as follows:

$$
\begin{aligned}
& q_{2 n}=\Delta \int_{\frac{p_{2 n}-p_{2 r}}{1-\alpha}}^{1} \mathrm{~d} F(v)=\Delta\left(1-\frac{p_{2 n}-p_{2 r}}{1-\alpha}\right) \\
& q_{2 r}=\Delta \int_{\frac{p_{2 r}}{\alpha}}^{\frac{p_{2 n}-p_{2 r}}{1-\alpha}} \mathrm{d} F(v)=\Delta\left(\frac{p_{2 n}-p_{2 r}}{1-\alpha}-\frac{p_{2 r}}{\alpha}\right)
\end{aligned}
$$

In the above analysis, the two-period manufacturing/ remanufacturing model is presented as follows:

$$
\begin{gathered}
\max _{p_{1}, p_{2 n}, p_{2 r}, \rho} \Pi_{2}=\left(p_{1}-c_{n}\right) q_{1}+\beta\left\{\left(p_{2 n}-c_{n}\right) q_{2 n}\right. \\
\left.\quad+\left(p_{2 r}-c_{r}\right) q_{2 r}-K \rho^{2} / 2\right\} \\
\text { s.t. } \quad q_{2 r} \leq \rho q_{1}
\end{gathered}
$$

where $\left(p_{1}-c_{n}\right) q_{1}$ represents the expected profit of the new products in the first period, $\left(p_{2 n}-c_{n}\right) q_{2 n}$ denotes the expected profit of the new products in the second period, $\left(p_{2 r}-c_{r}\right) q_{2 r}-K \rho^{2} / 2$ represents the expected profit of the remanufactured products in the second period, and $K \rho^{2} / 2$ 
is the fixed investment. The constraint indicates that the quantity of remanufactured products in the second period is restricted by the sales volume of the new products in the first period.

\subsubsection{Solutions}

In Eq. (4), the fixed investment function does not influence the concavity of the objective function, which remains concave. Moreover, the inequality constraint of Eq. (4) has the properties of convexity. Thus, the model has a unique optimal solution. Referred to [11], the
Lagrange function is constructed. The optimal policies are obtained according to the KKT Conditions, as displayed in Tab. 1 .

When $\rho<\rho^{\prime}=\frac{\alpha c_{n}-c_{r}}{\alpha(1-\alpha)\left(1-c_{n}\right)}, \lambda>0$, and the manufacturer remanufactures all acquired products, that is, $q_{2 r}=\rho q_{1}$. When $\rho \geq p^{\prime}, \lambda=0$, and the manufacturer does not remanufacture all acquired products, that is, $q_{2 r}<\rho q_{1}$.

Table 1 Optimal policies in the two-period case

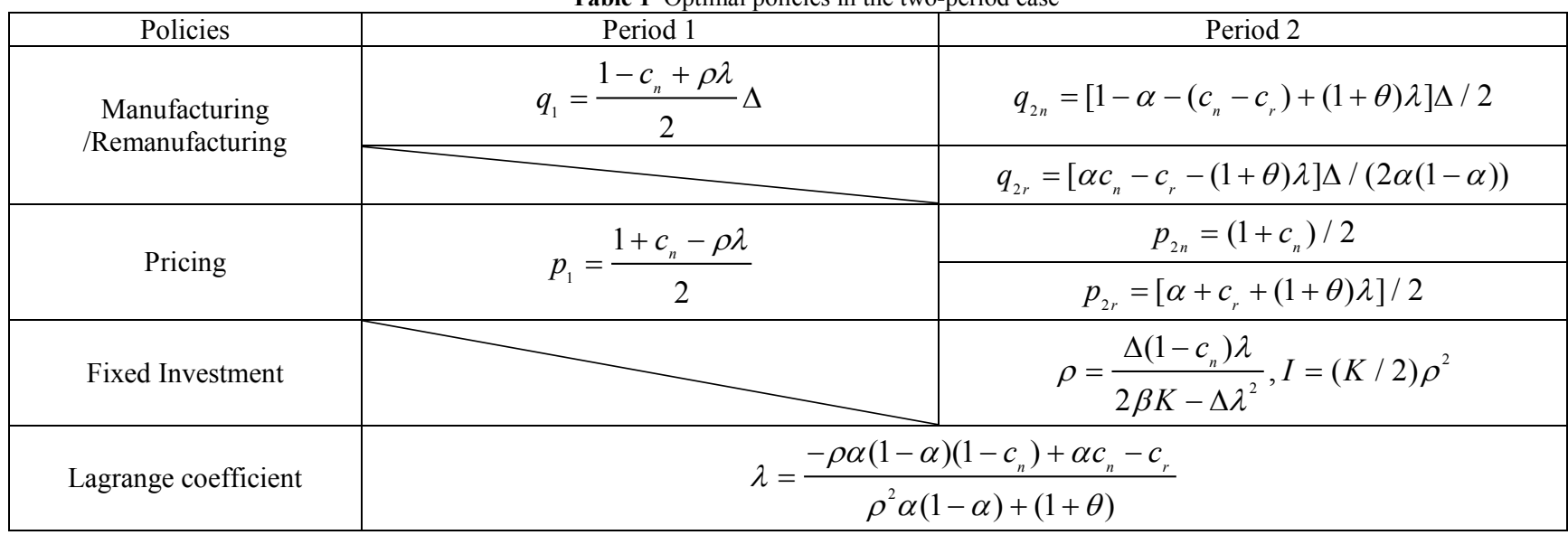

\subsection{Influence of fixed investment}

In Table 1, fixed investment remarkably influences the manufacturer's decision-making. First, the influence of fixed investment on the recycling ratio is analyzed through the investment coefficient.
Proposition 1. $\rho^{*}$ is decreasing in $K$ on the interval $\left(0, \rho^{\prime}\right)$.

Proof: The first-order derivatives of $\rho$ and $\lambda$ with respect to $K$ are:

$$
\begin{aligned}
\frac{\partial \lambda}{\partial K} & =\frac{\partial \lambda}{\partial \rho} \cdot \frac{\partial \rho}{\partial K}=\frac{\left(1-\alpha^{2}\right) \alpha^{2}\left(1-c_{n}\right)(1+\theta)}{\left[\alpha(1-\alpha) \rho^{2}+\theta+1\right]^{2}} \cdot\left[\rho^{2}-2 \rho^{\prime} \rho-\frac{(1+\theta)}{\alpha(1-\alpha)}\right] \frac{\partial \rho}{\partial K} \\
\frac{\partial \rho}{\partial K} & =\frac{\Delta\left(1-c_{n}\right) \frac{\partial \lambda}{\partial K}\left(2 \beta K-\Delta \lambda^{2}\right)-\Delta\left(1-c_{n}\right) \lambda\left(2 \beta-2 \Delta \lambda \frac{\partial \lambda}{\partial K}\right)}{\left(2 \beta K-\Delta \lambda^{2}\right)^{2}} \\
& =\left\{\frac{\partial \lambda}{\partial K}\left[\Delta\left(1-c_{n}\right)\left(2 \beta K-\Delta \lambda^{2}\right)+2 \Delta^{2}\left(1-c_{n}\right) \lambda^{2}\right]-2 \beta \Delta\left(1-c_{n}\right) \lambda\right\} /\left(2 \beta K-\Delta \lambda^{2}\right)^{2}
\end{aligned}
$$

Substituting Eq. (5) into Eq. (6), we obtain Eq. (7).

$$
\frac{\partial \rho}{\partial K}=\frac{2 \beta \Delta\left(1-c_{n}\right) \lambda}{\frac{\partial \lambda}{\partial \rho}\left[\Delta\left(1-c_{n}\right)\left(2 \beta K-\Delta \lambda^{2}\right)+2 \Delta^{2}\left(1-c_{n}\right) \lambda^{2}\right]-\left(2 \beta K-\Delta \lambda^{2}\right)^{2}}
$$

In addition,

$\frac{\partial \lambda}{\partial \rho}=\frac{\left(1-\alpha^{2}\right) \alpha^{2}\left(1-c_{n}\right)(1+\theta)}{\left[\alpha(1-\alpha) \rho^{2}+\theta+1\right]^{2}}\left[\rho^{2}-2 \rho^{\prime} \rho-\frac{(1+\theta)}{\alpha(1-\alpha)}\right]<0$.

$\Delta, \beta, 1-c_{n}, 2 \beta K-\Delta \lambda^{2}$, and $\lambda$ are all greater than 0 .
Hence, $\frac{\partial \rho}{\partial K}<0$, that is, $\rho$ is a decreasing function of $K$. Furthermore, $\frac{\partial \lambda}{\partial k}=\frac{\partial \lambda}{\partial \rho} \cdot \frac{\partial \rho}{\partial K}>0$.

Proposition 1 indicates that the investment coefficient is large when the remanufacturing system is underdeveloped. A high amount of fixed investment is 
required under the same recycling ratio, thereby reducing the enthusiasm of manufacturers for remanufacturing. The recycling ratio becomes low with few recyclable products for remanufacturing.

Next, the influences of fixed investment on other optimal policies are analyzed.

Corollary 1. (1) $p_{2 r}$ is increasing in $K$, and $p_{2 n}$ is free from the influence of the fixed investment. (2) $q_{2 n}$ is increasing in $K, q_{2 r}$ is decreasing in $K$, and the total quantity in the second period (that is, $q_{2 a}=q_{2 n}+q_{2 r}$ ) is decreasing in $K$.

Proof: (1) According to the first-order condition of $p_{2 r}$ with respect to $K$, we obtain $\frac{\partial p_{2 r}}{\partial K}=\frac{1}{2}(1+\theta) \frac{\partial \lambda}{\partial K}$. Due to $\frac{\partial \lambda}{\partial K}>0, \frac{\partial p_{2 r}}{\partial K}>0$. That is, $p_{2 r}$ is increasing in $K$. According to the expression of $p_{2 n}$ as presented in Table $1, p_{2 n}$ is irrelevant to $K$.

(2) According to the first-order condition of $q_{2 r}$ with respect to $K$, we obtain $\frac{\partial q_{2 n}}{\partial K}=\frac{\partial q_{2 n}}{\partial \lambda} \cdot \frac{\partial \lambda}{\partial K}=\frac{\Delta(1+\theta)}{2(1-\alpha)} \cdot \frac{\partial \lambda}{\partial K}$. Given $\lambda$ is increasing in $K$ in Proposition $1, \frac{\partial q_{2 n}}{\partial K}>0$, that is, $q_{2 n}$ is increasing in $K$.

Similarly, we obtain $\frac{\partial q_{2 r}}{\partial K}=\frac{\partial q_{2 r}}{\partial \lambda} \cdot \frac{\partial \lambda}{\partial K}=\frac{\partial \lambda}{\partial K} \cdot \frac{-\Delta(1+\theta)}{2(1-\alpha) \alpha}<0$ and $\frac{\partial q_{2 a}}{\partial K}=\frac{\partial q_{2 a}}{\partial \rho} \frac{\partial \rho}{\partial K}=\frac{-\Delta(1+\theta)}{2 \alpha} \cdot \frac{\partial \lambda}{\partial K}<0$. Therefore, $q_{2 r}$ and $q_{2 a}$ are decreasing in $K$.

Corollary 1 suggests that the recycling ratio decreases with increasing investment coefficient. Consequently, a few remanufactured products are salable in the market, and the manufacturer might increase the sale price of the remanufactured products. Moreover, the price of the new products remains the same in the second period, and the manufacturer may increase the quantity of the new products to cover the losses caused by fixed investment. However, the increased range is lower than the decreased range of the remanufactured products. Thus, the quantity of all products in the second period might decrease. That is, the investment coefficient may increase, leading to the shrinkage of the market, if the remanufacturing system is underdeveloped.

\subsection{Multi-period model}

In practice, constructing of the remanufacturing system usually involves many business links and stakeholders. Moreover, the manufacturer cannot finish the whole system construction in a single period because the corresponding fixed investment is huge. Thus, a multi- period implementation plan is practical. Furthermore, the fixed investment is minimal when the recycling ratio is the same for the gradual improvement of the remanufacturing system, that is, $K_{i-1}>K_{i}, i=3,4, \ldots, M$.

In the first period, the manufacturer only produces the new products. The manufacturer not only produces the new products but also remanufactures the recyclable products, which are sold in the previous period, starting from the second period. Thus, the multi-period manufacturing/remanufacturing model can be formulated as follows:

$$
\begin{gathered}
\max _{p_{1}, p_{i n}, q_{i n}, p_{i r}, q_{i r}, \rho_{i}} \Pi_{M R}=\left(p_{1}-c_{n}\right) q_{1}+\sum_{i=2}^{M} \beta^{i-1} \times \\
\quad\left[\left(p_{i n}-c_{n}\right) q_{i n}+\left(p_{i r}-c_{r}\right) q_{i r}-K_{i} \rho_{i}^{2} / 2\right] \\
\text { s.t. } \quad q_{2 r} \leq \rho_{2} q_{1} \\
q_{i r} \leq \rho_{i} q_{i-1, n} \quad i=2,3, \ldots, M \\
K_{i-1}>K_{i} \quad i=3,4, \ldots, M
\end{gathered}
$$

where $\quad q_{1}=\Delta\left(1-p_{1}\right) \quad, \quad q_{i n}=\Delta\left(1-\frac{p_{i n}-p_{i r}}{1-\alpha}\right)$, $q_{i r}=\Delta \frac{\alpha p_{i n}-p_{i r}}{(1-\alpha) \alpha}$, and $\beta=1 /(1+\theta)$.

In Eq. (8), $\left(p_{1}-c_{n}\right) q_{1}$ represents the expected profit of the new products in the first period, $\left(p_{i n}-c_{n}\right) q_{i n}$ denotes the expected profit of the new products in period $i,\left(p_{i r}-c_{r}\right) q_{i r}-K_{i} \rho_{i}^{2} / 2$ represents the expected profit of the remanufactured products in period $i$, and $K_{i} \rho_{i}^{2} / 2$ is the fixed investment in period $i$. The constraint refers to the limitation of the quantity of the new products in the previous period on the quantity of the remanufactured products in the subsequent period.

According to the KKT conditions, the optimal policies of the manufacturer in multi-period case can be obtained, as displayed in Tab. 2.

Compared with the optimal solutions obtained by [8] under the homogeneous demand, the optimal solutions under the heterogeneous demands are also closely connected to the coefficient of the public awareness of environmental protection (that is, $\alpha$ ), apart from the influences of the costs of the new and remanufactured products and the investment coefficient of different periods. The optimal recycling ratio $\rho_{i}$ in period $i$ and the optimal recycling ratio of the adjacent periods, $\rho_{i-1}$ and $\rho_{i+1}$, are mutually influenced.

In Tab. 2, the optimal policies in the multi-period case are complex, and the analytical approach is hardly adopted to analyze the influences of various factors on the optimal policies. Thus, the optimal policies in the multiperiod case are analyzed using the numerical simulation in the following section. 
Table 2 Optimal policies in the multi-period case

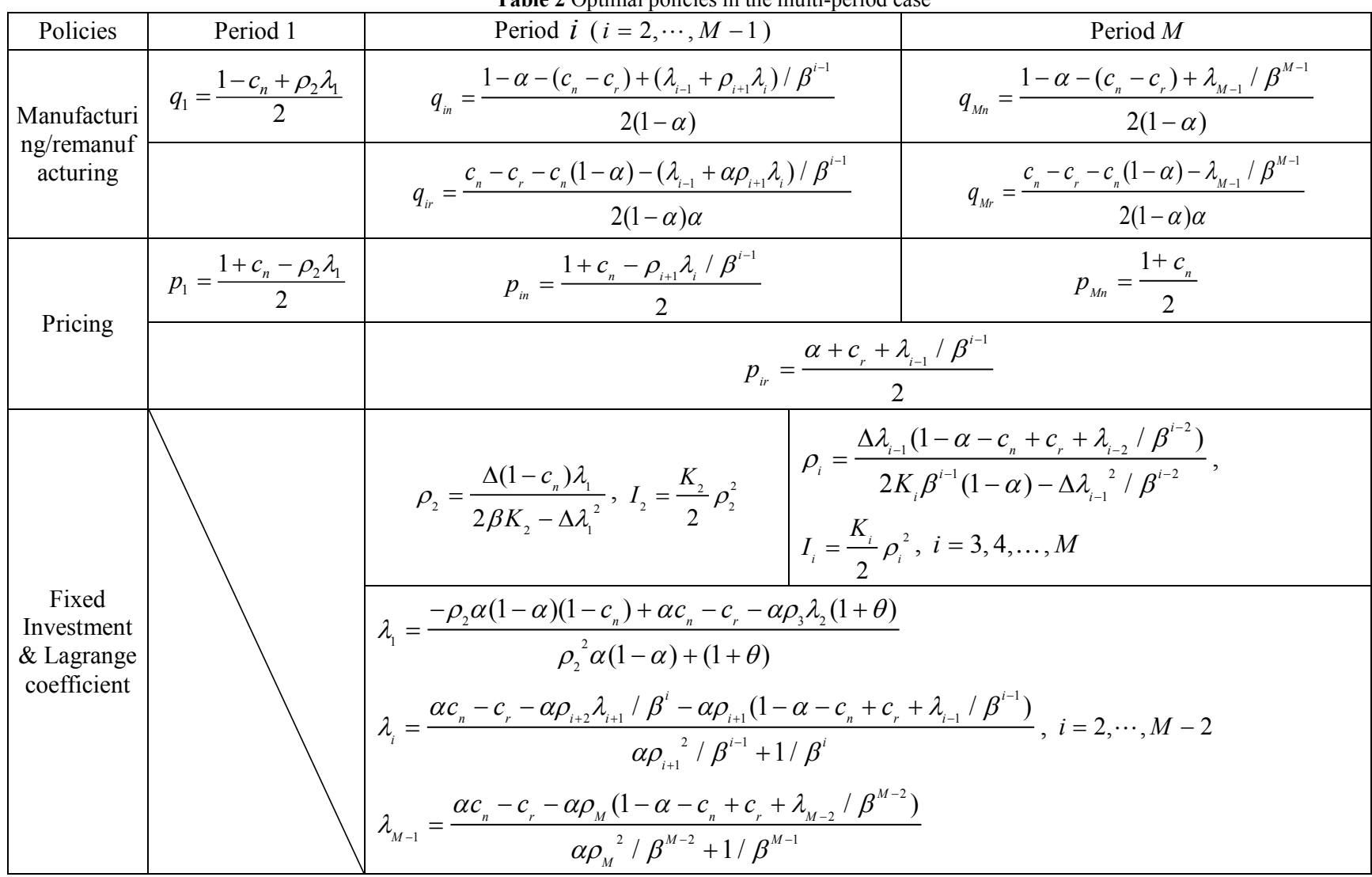

\section{Result analysis and discussion}

Numerical experiments are conducted in the two- and multi-period cases to validate the effectiveness of the proposed model and test the influence of fixed investment.

\subsection{Numerical simulation in the two-period case}

In example 1 , the parameters are set as $\Delta=1, c_{n}=$ $0.8, c_{r}=0.5, \alpha=0.75$, and $\theta=1 / 9$. The recycling ratio, fixed investment, profits, and quantity and price of the new and remanufactured products change accordingly with changes of the investment coefficient $K$ on the interval $[0.03,0.21]$, as illustrated in Figs. 1-5.

In Figs. 1-5, the manufacturer is unwilling to launch remanufacturing when the investment coefficient is high. Based on this illustration, the manufacturer may reduce the fixed investment and acquire few recyclable products for remanufacturing. The manufacturer can raise the sale price of the remanufactured and new products to ensure the profit of the manufacturing system. In addition, the manufacturer can increase the quantity of the new products in the second period to cover the market losses of remanufactured products. However, the total quantity and profit in the two periods are decreasing with the increase of the investment coefficient. These results are consistent with the results of Proposition 1 and Corollary 1.

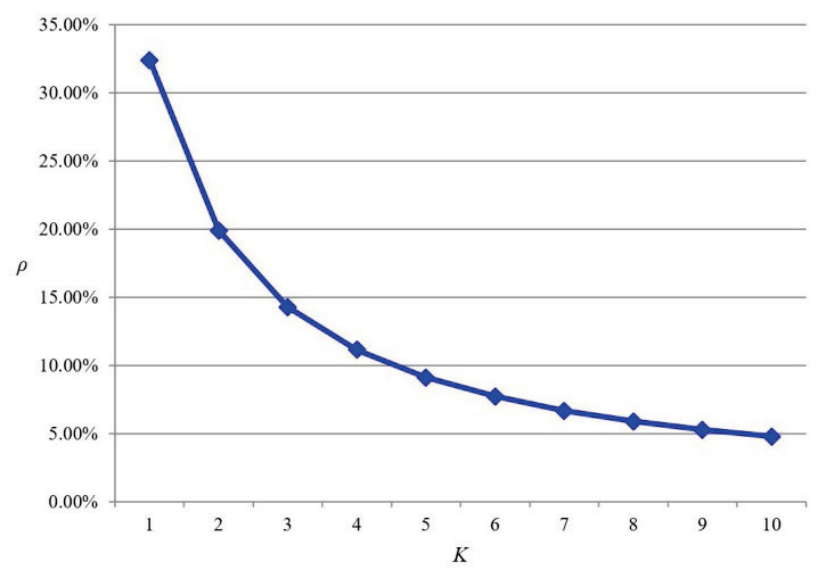

Figure 1 Recycling ratio under different investment coefficients

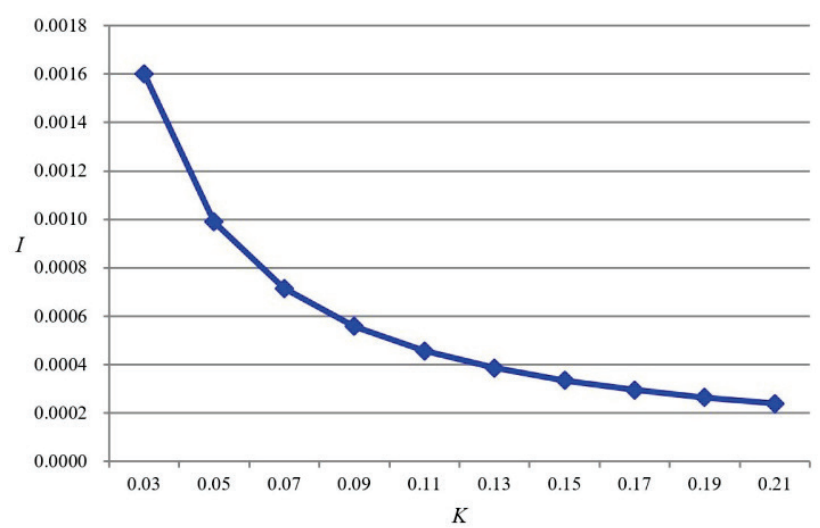

Figure 2 Fixed investment under different investment coefficients 


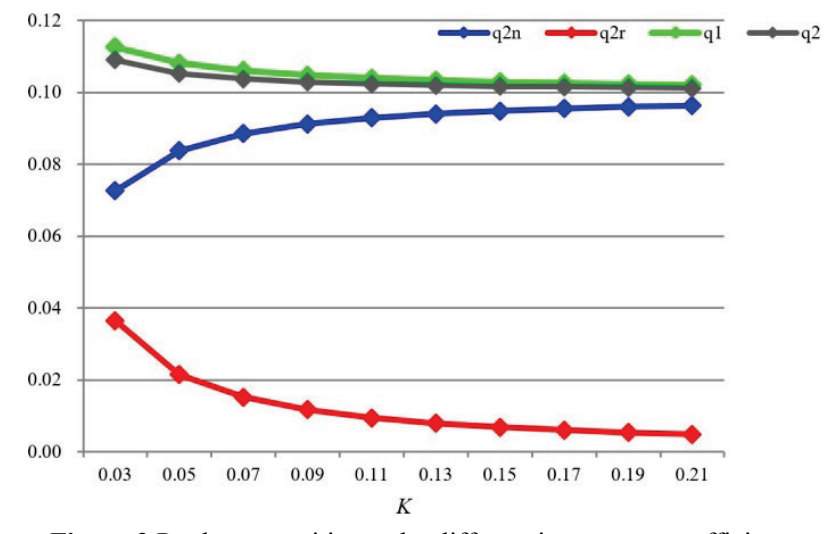

Figure 3 Product quantities under different investment coefficients

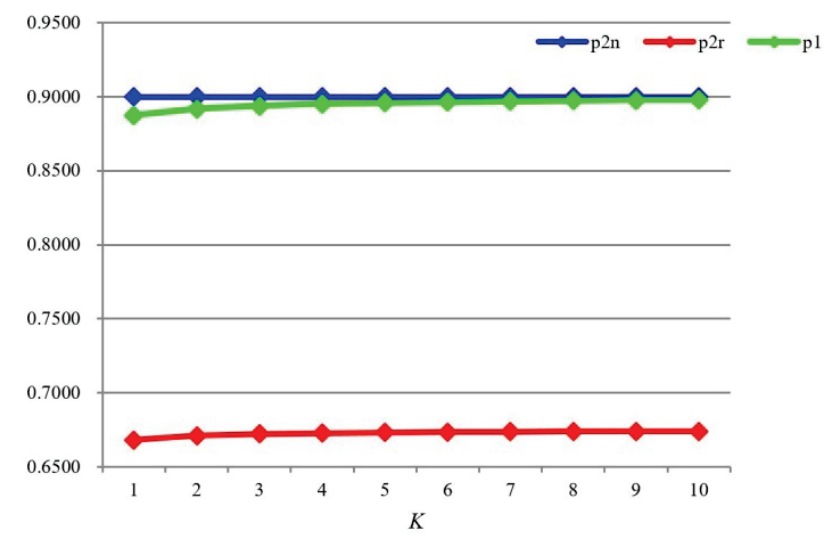

Figure 4 Sale price under different investment coefficients

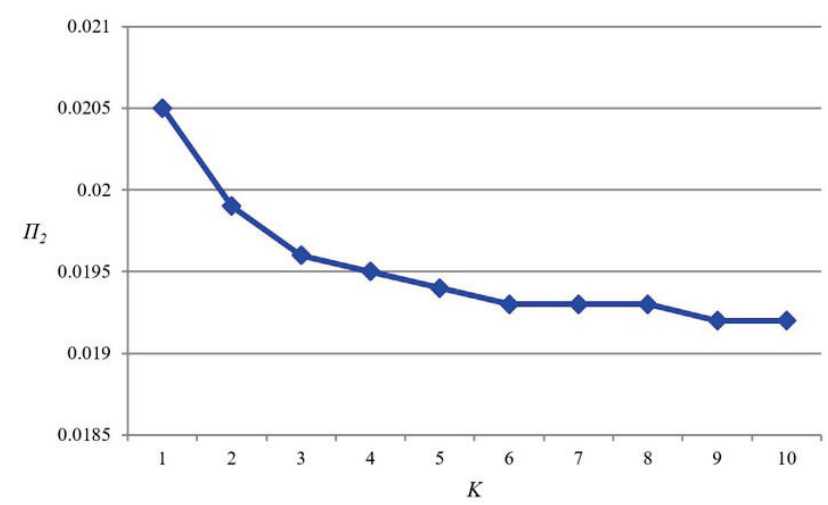

Figure 5 Total system profit under different investment coefficients

\subsection{Numerical simulation in the multi-period case}

In example 2, the optimal policies are discussed in six periods. The parameters are set as $\Delta=1, c_{n}=0.8$, $c_{r}=0.5, \alpha=0.75$, and $\theta=1 / 9$. The setting of the investment coefficients is listed in Tab. 3.

Table 3 Setting of investment coefficients

\begin{tabular}{|c|c|c|c|c|c|c|}
\hline $\begin{array}{c}\text { Period } \\
\text { Case }\end{array}$ & 1 & 2 & 3 & 4 & 5 & 6 \\
\hline $\begin{array}{c}\text { Case 1: The } \\
\text { investment } \\
\text { coefficients are } \\
\text { relatively large }\end{array}$ & - & 0.30 & 0.25 & 0.20 & 0.10 & 0.05 \\
\hline $\begin{array}{c}\text { Case 2: The } \\
\text { investment } \\
\text { coefficients are } \\
\text { relatively minimal }\end{array}$ & - & 0.10 & 0.08 & 0.06 & 0.04 & 0.02 \\
\hline
\end{tabular}

The optimal policies are obtained in the two cases, as depicted in Figs. 6-9.

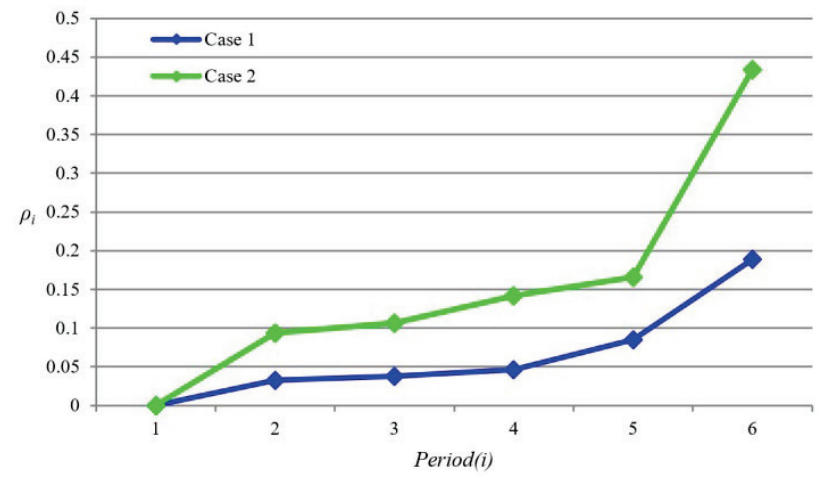

Figure 6 Recycling ratio in different cases

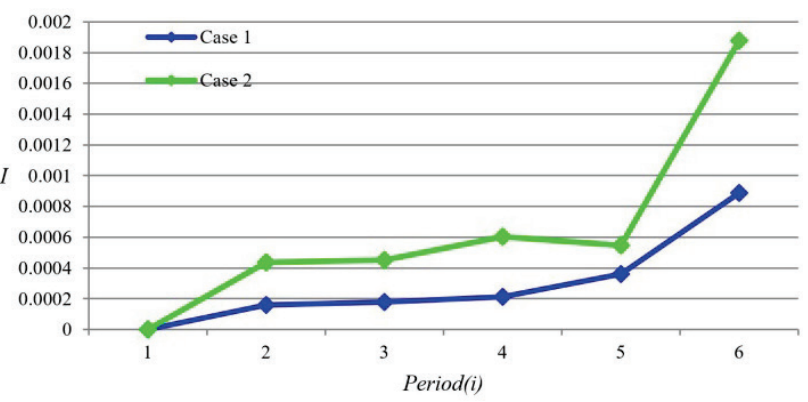

Figure 7 Fixed investment in different cases

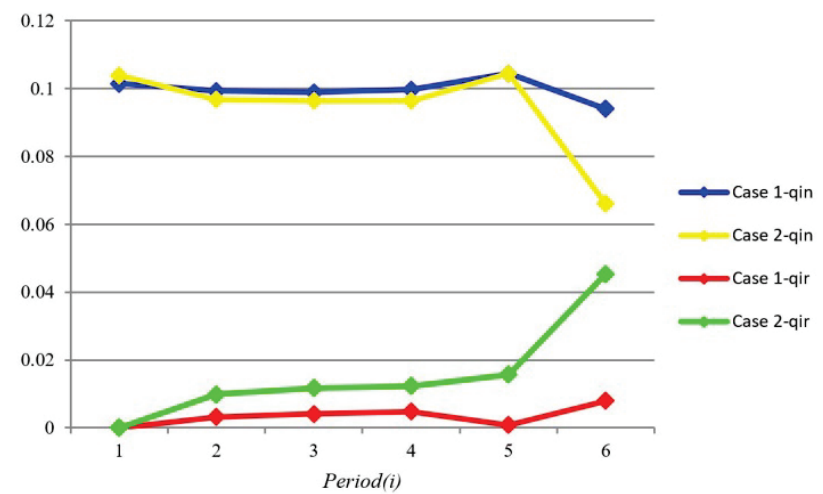

Figure 8 Product quantities in different cases

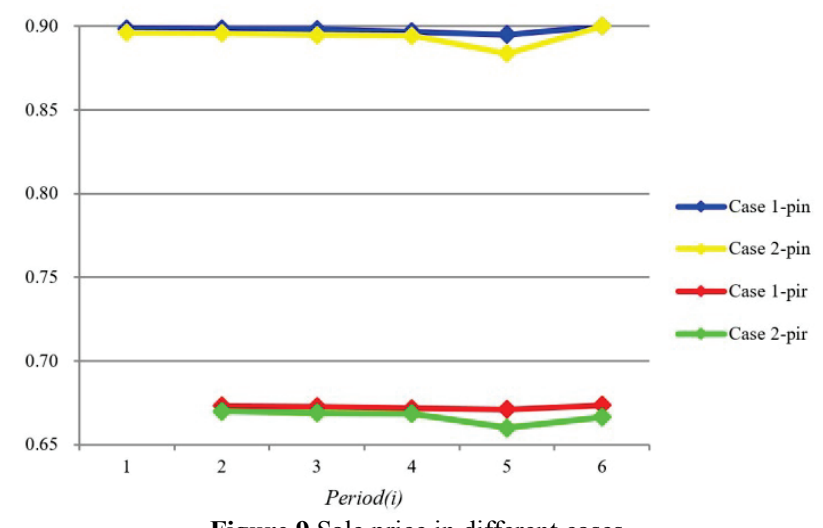

Figure 9 Sale price in different cases

Figs. 6-9 demonstrate that the optimal policies in the two cases are nearly similar. The remanufacturing system is improving with gradually decreasing investment coefficients, and the fixed investment steadily declines at a given recycling ratio. Consequently, the willingness to remanufacture is robust, and the recycling ratio increases 
gradually. The sale price constantly decreases with the increasing quantity of remanufactured products, but the profits from remanufacturing increase. This result prompts the manufacturer to invest further in improving the remanufacturing system. Therefore, the manufacturer may further decrease the sale price of the new products in the prior stage to increase the quantity of the new products (excluding Period 6) to guarantee sufficient recyclable products.

The comparison of the optimal policies in the two cases illustrated in Figs. 6-9 implies that the manufacturer's remanufacturing willingness is weak when the investment coefficient is high and the available fixed investment for improving remanufacturing system is minimal. Thus, the manufacturer may limit the remanufacturing business, leading to low recycling ratio and quantity of the remanufactured products. The manufacturer also requires raising the quantity and sale price of the new products to cover the losses incurred by remanufacturing. Correspondingly, the sale price of the remanufactured products may decrease (excluding Period 6).

\section{Conclusion}

To clarify the negative influences of fixed investment on the manufacturer's manufacturing/ remanufacturing business, this study analyzed the correlation between fixed investment and recycling ratio. The two- and multi-period manufacturing/ remanufacturing models were developed under the heterogeneous demands. The optimal policies were obtained based on the KKT conditions. Finally, the influence of the fixed investment on the optimal policies was discussed. The following conclusions were obtained:

(1) A high investment coefficient means a high degree of underdevelopment of remanufacturing system, indicating that the remanufacturing business is difficult to establish.

(2) In the two-period case, an increase in the investment coefficient results in reduced enthusiasm of the manufacturer to engage in remanufacturing. Correspondingly, the recycling ratio will decrease, resulting in the reduced quantity of remanufactured products. The total quantity and profit generally decline, although the manufacturer can raise the sale price of the products to alleviate the losses caused by the decreasing quantity.

(3) In the multi-period case, the manufacturer gradually increases the fixed investment to improve the remanufacturing system and then strengthens the remanufacturing willingness. The manufacturer will reduce the sale price of the products under this scenario, but increase the quantity of the new and remanufactured products to meet the increasing demands. If the degree of underdevelopment of the remanufacturing system is high, then the investment coefficient of the different periods will be high, and the manufacturer will adjust to the situation by raising the quantity and sale price of the new products.

This study focused on the scenario where manufacturers are faced with huge fixed investment because of the underdeveloped remanufacturing system and provided effective and feasible reference on selecting the optimal manufacturing/remanufacturing policies. However, this study has its limitations. For example, the influence of government environmental protection policies (i.e., statutory recycling ratio and government subsidies) is not studied. The influences of fixed investment under government environmental protection policies may be studied in the future. In addition, the manufacturing/remanufacturing problem under different carbon emission regulations is worthy of study.

\section{References}

[1] Guide Jr., V. D. R.; Van Wassenhove, L. N. The evolution of closed-loop supply chain supply chain research. // Operations Research. 57, 1(2009), pp. 10-18. https://doi.org/10.1287/opre.1080.0628

[2] Yang, C. H.; Liu, H. B.; Ji, P.; Ma, X. Optimal Acquisition and Remanufacturing Policies for Multi-Product Remanufacturing Systems. // Journal of Cleaner Production. 135, (2016), pp. 1571-1579. https://doi.org/10.1016/j.jclepro.2015.10.057

[3] Smith, V. M.; Keoleian, G. A. The value of remanufactured engines: life-cycle environmental and economic perspectives. // Journal of Industrial Ecology. 8, 1-2(2004), pp. 193-221. https://doi.org/10.1162/1088198041269463

[4] Guide Jr., V. D. R.; Jayaraman, V. Product acquisition management: current industry practice and a proposed framework. // International Journal of Production Research. 38, 16(2000), pp. 3779-3800. https://doi.org/10.1080/00207540050176003

[5] Hyun Bok Lee; Nam Wook Cho; Yoo Suk Hong. A hierarchical end-of-life decision model for determining the economic levels of remanufacturing and disassembly under environmental regulations. // Journal of Cleaner Production. 18, (2010), pp. 1276-1283. https://doi.org/10.1016/j.jclepro.2010.04.010

[6] Esenduran, G.; Kemahhoglu-Ziya, E.; Swaminathan, J. M. Impact of take-back regulation on the remanufacturing industry. // Production and Operations Management. 26, 5(2017), pp. 924-944. https://doi.org/10.1111/poms.12673

[7] Parsa, H. G.; Lord, K. R.; Putrevu, S.; Kreeger, J. Corporate social and environmental responsibility in services: Will consumers pay for it? // Journal of Retailing and Consumer Services. 22, (2015), pp. 250-259. https://doi.org/10.1016/j.jretconser.2014.08.006

[8] Yang, C. H.; Liu, L. Y.; Zhang, L. Optimal Acquisition and Pricing Policies for Remanufacturing Systems with Initial Investment. // Computer Modelling \& New Technologies. $18,5(2014)$, pp. 220-225.

[9] Wei, S.; Tang, O.; Sundin, E. Core (product) Acquisition Management for remanufacturing: a review. // Journal of Remanufacturing. 5, 1(2015), pp. 1-27. https://doi.org/10.1186/s13243-015-0014-7

[10] Kleber, R.; Minner, S.; Kiesmüller, G. A continuous time inventory model for a product recovery system with multiple options. // International Journal of Production Economics. 79, 2(2002), pp. 121-141. https://doi.org/10.1016/S0925-5273(02)00256-6

[11] Ferrer, G.; Swaminathan, J. M. Managing new and differentiated remanufactured products. // European Journal of Operational Research. 203, 2(2010), pp. 370-379. https://doi.org/10.1016/j.ejor.2009.08.007

[12] Guide Jr., V. D. R.; Li, J. The potential for cannibalization of new products sales by remanufactured products. // Decision Sciences. 41, 3(2010), pp. 547-572. https://doi.org/10.1111/j.1540-5915.2010.00280.x 
[13] Wang, J.; Zhao, J.; Wang, X. Optimum policy in hybrid manufacturing/remanufacturing system. // Computers \& Industrial Engineering. 60, 3(2011), pp. 411-419. https://doi.org/10.1016/j.cie.2010.05.002

[14] Shi, J.; Zhang, G.; Sha, J. Optimal production planning for a multi-product closed loop system with uncertain demand and return // Computers \& Operations Research. 38, 3(2011), pp. 641-650. https://doi.org/10.1016/j.cor.2010.08.008

[15] Li, X; Li, Y; Saghafian, S. A hybrid manufacturing/ remanufacturing system with random remanufacturing yield and market-driven product acquisition // IEEE Transactions on Engineering Management, 60, 2 (2013), pp. 424-437. https://doi.org/10.1109/TEM.2012.2215873

[16] Cai, X.; Lai, M.; Li, X. et al. Optimal acquisition and production policy in a hybrid manufacturing/ remanufacturing system with core acquisition at different quality levels. // European Journal of Operational Research. 233, 2(2014), pp. 374-382. https://doi.org/10.1016/j.ejor.2013.07.017

[17] Bulmus, S. C.; Zhu, S. X.; Teunter, R. Competition for cores in remanufacturing. // European Journal of Operational Research. 233, 1(2014), pp. 105-113. https://doi.org/10.1016/j.ejor.2013.08.025

[18] Ferguson, M.; Toktay, L. B. The effect of competition on recovery strategies. // Management Science. 15, 3(2008), pp. 351-368.

[19] Debo, L. G.; Toktay, L. B.; Van Wassenhove, L. N. Market segmentation and product technology selection for remanufacturable products. // Management Science. 51, 8(2005), pp. 1193-1205. https://doi.org/10.1287/mnsc.1050.0369

[20] Savaskan, R. C.; Bhattacharya, S.; Van Wassenhove, L. N. Closed-loop supply chain models with product remanufacturing. // Management science. 50, 2(2004), pp. 239-252. https://doi.org/10.1287/mnsc. 1030.0186

\section{Authors' addresses}

Xiang Lv, Ph.D. candidate

Room 424, School of Economics \& Management, Xi'an University of Technology, Yanxiang Road, Xi'an, 710054, Shanxi Province, P. R. China

E-mail: lvxiangg@163.com

\section{Jian-Hua Huang, Ph.D., Associate Professor}

(Corresponding author)

Room 308, School of Economics \& Management, Fuzhou

University, No. 2 Xueyuan Road, Fuzhou, 350108, FuJian

Province, P. R. China.

E-mail: everam@sina.com

\section{Hai-Bo Liu, Ph.D. candidate}

Marketing Discipline Group, Business School,

University of Technology Sydney,

Building 8, 14-28 Ultimo Road, Ultimo, NSW, 2007, Australia

E-mail: Haibo.Liu@student.uts.edu.au 